\title{
Electrolyte-cathode interactions in 5-V lithium-ion cells
}

\author{
Wolfram Kohs ${ }^{1}$ (D) Jürgen Kahr ${ }^{1} \cdot$ Anwar Ahniyaz $^{2} \cdot$ Ningxin Zhang $^{1} \cdot$ \\ Atanaska Trifonova ${ }^{1}$
}

Received: 3 February 2017 / Accepted: 13 July 2017 / Published online: 10 August 2017

(C) The Author(s) 2017. This article is an open access publication

\begin{abstract}
The electrolyte/electrode interactions on the anode side of a lithium-ion cell and the formation of the solid electrolyte interphase (SEI) have been investigated intensively in the past and are fairly well understood. Present knowledge about the reactions on the cathode side and the resulting cathode electrolyte interphase (CEI) is less detailed. In this study, the electrolyte/electrode interactions on the surface of the high-voltage cathode material $\mathrm{LiNi}_{0.5} \mathrm{Mn}_{1.5} \mathrm{O}_{4}$ (LNMO), both bare and $\mathrm{FePO}_{4}$-coated, were investigated. The gases evolving upon first time charging of the system were investigated using a GC/MS combination. The degradation products included THF, dimethyl peroxide, phosphor trifluoride, 1,3-dioxolane and dimethyl difluor silane, formed in the GC's column as its coating reacts with HF from the experiments. Although these substances and their formation are in themselves interesting, the absence of many degradation products which have been mentioned in the existing literature is of equal interest. Our results clearly indicate that coating a cathode material can have a major influence on the amount and composition of the gaseous decomposition products in the formation phase.
\end{abstract}

\section{Introduction}

Lithium-ion batteries are the state of the art energy storage system for all scales of electric applications ranging from small mobile phones, via electric tools up to electric vehicles.

Wolfram Kohs

wolfram.kohs@ait.ac.at; kwolfi74@gmail.com

1 AIT Austrian Institute of Technology GmbH, Vienna, Austria

2 SP Sveriges Tekniska Forskningsinstitut AB, Borås, Sweden
While $\mathrm{LiCoO}_{2}$ was used as cathode material in the first lithium-ion cells by Sony in 1991 [1], today $\mathrm{LiMn}_{2} \mathrm{O}_{4}$ ( $\mathrm{LMS}$ ), $\mathrm{LiNi}_{0.33} \mathrm{Mn}_{0.3} \mathrm{Co}_{0.33} \mathrm{O}_{2}$ ( $\mathrm{NMC}$ ), $\mathrm{LiNi}_{0.80} \mathrm{Co}_{0.15} \mathrm{Al}_{0.05} \mathrm{O}_{2}$ (NCA) and $\mathrm{LiFePO}_{4}$ (LFP) are widely used.

To further increase the energy density of the batteries, highcapacity materials and high-potential materials are being investigated. High-capacity materials are usually derived from the class of layered oxides $[2,3]$. The phospho-olivine type $\mathrm{LiMPO}_{4}(\mathrm{M}=\mathrm{Co}, \mathrm{Mn}, \mathrm{Ni})$ materials [4-6] and the spinel type materials $\mathrm{LiM}_{\mathrm{x}} \mathrm{Mn}_{2-\mathrm{x}} \mathrm{O}_{4}(\mathrm{M}=\mathrm{Ni}, \mathrm{Fe}, \mathrm{Cr}, \mathrm{Co})$ [6-9] belong to the high-voltage materials, the latter showing a higher electronic conductivity than the former $[10,11]$.

Among the group of high-voltage spinels, the nickelsubstituted $\mathrm{Mn}$ spinel $\mathrm{LiNi}_{\mathrm{x}} \mathrm{Mn}_{2-\mathrm{x}} \mathrm{O}_{4}$ (LNMO) is considered to be one of the most promising materials $[10,11]$. The term $\mathrm{LiNi}(\mathrm{II})_{\mathrm{x}} \mathrm{Mn}(\mathrm{III})_{1-2 \mathrm{x}+2 \delta} \mathrm{Mn}(\mathrm{IV})_{1+\mathrm{x}-2 \delta} \mathrm{O}_{4-\delta}$ describes the LNMO system and the possible oxidation stages. The nickel content and the oxygen deficiency determine the electrochemical properties of the material. The two redox pairs formed by the two transition metals determine the lithium insertion/ deinsertion potentials of LNMO, the 4.1-V plateau due to the oxidation of $\mathrm{Mn}(\mathrm{III})$ to $\mathrm{Mn}(\mathrm{IV})$ and the $4.7-\mathrm{V}$ plateau due to the oxidation of $\mathrm{Ni}(\mathrm{II})$ to $\mathrm{Ni}(\mathrm{IV})$. The fully $\mathrm{Ni}$ substituted structure follows the formula $\mathrm{LiNi}_{0.5} \mathrm{Mn}_{1.5} \mathrm{O}_{4}$, which means all $\mathrm{Mn}$ is $\mathrm{Mn}(\mathrm{IV})$, thus avoiding both $\mathrm{Mn}(\mathrm{III})$ and its concomitant, undesirable Mn dissolution and the Jahn Teller effect [11].

The main problem of LNMO is its limited cycling stability, which is caused by the attack of $\mathrm{HF}$, found in traces in $\mathrm{LiPF}_{6}$ electrolytes and formed by the reaction of the latter with water impurities. The HF leads to Mn and Ni dissolution [10]. Certain electrolytes and their additives have been found to enhance the stability of the high-voltage cathode materials; however, compared to anodes, the reactions between the 
cathode and the electrolyte have not been explained in great detail so far [12-14].

The formation of an effective cathode electrolyte interphase (CEI), which is especially critical for high-voltage cathode materials, has not been solved satisfactorily for these materials to date. Thermodynamically, the conventionally used electrolytes are oxidised at potentials of more than $4.5 \mathrm{~V}$; the numerous existing positive results are explained by kinetic effects, cf. the stability of sulfuric acid electrolyte in lead acid batteries [15]. Different additives, e.g. LiBOB and LiBOB derivates, new solvents, e.g. ionic liquids, sulfones, substituted sulfones, and sulfolane are being intensively studied to overcome the degradation problems at high potentials. In electrode engineering, where a stable high-voltage system for a safer, higher-performing lithium-ion battery is desired, dopings and coatings of the active materials are being investigated to stabilise the materials and to facilitate formation of an effective CEI [15-19].

In this work, we report a closer look into the electrolyteLNMO interactions by measuring the resulting decomposition products via gas chromatography-mass spectrometry $(\mathrm{GC} /$ MS) [20]. The aim of the investigations was to obtain deeper insight into the reactions and the degradation mechanisms that occur.

\section{Experimental}

LNMO preparation The LNMO was synthesised by carbonate decomposition. A stoichiometric mixture $\left(\mathrm{Li}_{1.0} \mathrm{Ni}_{0.5} \mathrm{Mn}_{1.5} \mathrm{O}_{4}\right)$ of metal carbonate salts $\left(\mathrm{Li}_{2} \mathrm{CO}_{3}, \mathrm{NiCO}_{3}\right.$ and $\mathrm{MnCO}_{3}$ ) was mixed by hand in an agar mortar for about $10 \mathrm{~min}$, moved into an alumina crucible and calcined at $450{ }^{\circ} \mathrm{C}$ (heating rate $3^{\circ} \mathrm{C} \mathrm{min}^{-1}$ ) for $1 \mathrm{~h}$, and then calcined again at $850{ }^{\circ} \mathrm{C}$ for $18 \mathrm{~h}$ (heating rate $3{ }^{\circ} \mathrm{C} \mathrm{min}{ }^{-1}$ ) to obtain LNMO.

For the $\mathrm{FePO}_{4}$ coating, a $2.8 \%(w / w) \mathrm{LNMO}$ water dispersion was prepared by mixing $6.79 \mathrm{~g}$ LNMO powder into $244.67 \mathrm{~g}$ of water and stirring overnight with a magnetic stirrer. In order to improve the dispersion of the LNMO particles, the dispersion was sonicated in a sonication bath (ultrasonic cleaner USC-THD) for $90 \mathrm{~min}$. Laser diffraction analysis measurements indicated that the particle size of LNMO was around $5 \mu \mathrm{m}$ (D50).

Afterwards, a suitable amount of diluted aqueous solution of $\left(\mathrm{NH}_{4}\right)_{2} \mathrm{HPO}_{4}$ and $\mathrm{Fe}\left(\mathrm{NO}_{3}\right)$ was added dropwise into the mixture under stirring to obtain $3 \mathrm{wt} \% \mathrm{FePO}_{4}$-coated LMNO. Consequently, $\mathrm{FePO}_{4}$ was formed and deposited onto the surface of the LMNO particles. After repeated rinsing and filtering at $5000 \mathrm{rpm}$ for $5 \mathrm{~min}$, the cake was first dried at $120^{\circ} \mathrm{C}$ for $12 \mathrm{~h}$ and then heated at $400{ }^{\circ} \mathrm{C}$ for $6 \mathrm{~h}$. Finally, a $3.0 \mathrm{wt} \% \mathrm{FePO}_{4}$ coated LMNO sample was obtained.

To analyse the structure of the LNMO samples, the X-ray diffraction (XRD) patterns of the samples were collected with a Philips PANalytical X' pert X-ray diffractometer equipped with a monochromatized $\mathrm{Cu} \mathrm{K} \alpha 1$ radiation between $10^{\circ}$ and $60^{\circ}$ at a scan rate of $0.02^{\circ} / \mathrm{s}$.

The morphology of the samples was observed through environmental scanning electron microscopy (FEI Quanta 600 FEG Environmental Scanning Electron Microscope); for the specific surface measurements, a quantachrome autosorb iQ ASIQC0000-3 was used. The standard seven-point program of the system was used for all measurements.

Electrode preparation A PVdF solution of $8 \%(w / w)$ in NMP - was prepared and stirred for at least $24 \mathrm{~h}$, and if necessary heated to $50{ }^{\circ} \mathrm{C}$ until the solution was clear. The cathode material and the conductive additive (CA), Imerys C65, were dried together at $120^{\circ} \mathrm{C}$ under vacuum for $10 \mathrm{~h}$. The active material (AM), typically in amounts of $3-4 \mathrm{~g}$, and carbon black were gently mixed in a pestle and mortar by hand; then, the PVdF solution was added until a mass balance of AM:CA:PVdF $=90: 5: 5(w / w)$ was obtained. Then, mixture was kneaded with a pestle and mortar by hand for about 30 min until reaching a pasty consistency. Then, the mixture was transferred into a small beaker glass and diluted with NMP and stirred for at least $4 \mathrm{~h}$; more NMP was added as needed to reach the desired consistency.

The slurry was coated on a cleaned aluminium foil with a doctor blade, $100 \mu \mathrm{m}, 3 \mathrm{~mm} \mathrm{sec}^{-1}$. The foils were dried at room temperature for $10 \mathrm{~h}$ and then heated at $60^{\circ} \mathrm{C}$ for $15 \mathrm{~min}$ and at $150{ }^{\circ} \mathrm{C}$ for $30 \mathrm{~min}$ under vacuum.

Electrodes were punched into disks of $15 \mathrm{~mm}$ diameter, pressed with $5 \mathrm{t}\left(2800 \mathrm{~kg} \mathrm{~cm}^{-2}\right)$, weighted, heated at $120{ }^{\circ} \mathrm{C}$ for $12 \mathrm{~h}$ under vacuum and transferred into an argon-filled glove box (MBraun), where the water and oxygen content in the atmosphere was below $1 \mathrm{ppm}$.

Electrochemical characterisation The electrodes, each containing 11-13 mg LNMO, were characterised in 2032 type coin cells, using a half-cell setup, a $170-\mu \mathrm{m}$ lithium foil as a counter/reference electrode and $1 M \mathrm{LiPF}_{6}, \mathrm{EC}: \mathrm{EMC}=3: 7$ with $2 \%$ fluoroethylene carbonate (FEC) as electrolyte, 70 to $75 \mu \mathrm{l}$, with one single layer of Whatman separator (GF/A).

The cyclovoltammograms were made with $50 \mu \mathrm{V} \mathrm{s}^{-1}$ in a potential window of 3.5 to $5.0 \mathrm{~V}$ vs. $\mathrm{Li}^{2} \mathrm{Li}^{+}$, before and after the CV's EIS experiments were made, the amplitude being $20 \mu \mathrm{A}$ at $500 \mathrm{kHz}$ to $0.1 \mathrm{~Hz}$, the higher frequencies being neglected. The experiments were made at $25{ }^{\circ} \mathrm{C}$ using Princeton Ametek VersaSTAT 3 potentiostats, SW VersaStudio SW 2.44.4.

The cycling tests were made with a Maccor cycling system, SW MR 3.1.625; again using the potential range of 3.5 to $5.0 \mathrm{~V}$ vs. $\mathrm{Li} / \mathrm{Li}^{+}$, the first cycle was performed with a rate of $\mathrm{C} / 20$ followed by a CCCV/CC characterisation consisting of 3 cycles of $C / 10,3$ cycles $C / 5,3$ cycles $1 \mathrm{C}$ and 3 cycles $\mathrm{C} / 10$; the $\mathrm{CV}$ step was ended by the current dropping below $\mathrm{C} / 20$. 
Electrolyte-cathode interactions For studying the electrolytecathode interactions, an ECC-DEMS type cell from EL cell was used. The cathode, the same dimensions as described above, was arranged at the bottom of the cell. Two layers of Whatman (GF/ A) separator were used, with an excess of $240 \mu$ electrolyte; lithium foil was used as a counter/reference electrode. The gas in- and outlets were sealed, and the cell was left in the glove box overnight.

Electrochemical measurements were conducted on a BioLogic VSP-VMP3B-20 potentiostat, SW EC-Lab V10.44. The gas outlet was connected to a Shimadzu QP2010Plus Quadrupol-GC/MS-System. After establishing a gas flow of $0.8-1.2 \mathrm{ml} \mathrm{min}^{-1}$, the cell was left at $\mathrm{OCV}$ to equilibrate again from the pressure disturbances for 2 to $3 \mathrm{~h}$. Then, a CV was started, $50 \mu \mathrm{V} / \mathrm{s}$, from OCV to 5.0 to $3.5 \mathrm{~V}$, and every $30 \mathrm{~min}$, a volume of $500 \mu \mathrm{l}$ was taken from the loop and analysed by the GC/MS combination. GC/MS Postrun Analysis Version 4.11 (Labsolutions) was used for the GC/MS data processing; identification of the individual substances was done by computerised matching of the measured mass spectra with those of the NIST21 and NIST107 mass spectra libraries.

The GC/MS setup was as follows: injection temperature $200{ }^{\circ} \mathrm{C}$, linear velocity $50 \mathrm{~cm} \mathrm{~s}^{-1}$, column flow $1.93 \mathrm{ml} \mathrm{min}^{-1}$,

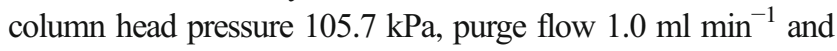
split ratio 8.0; a Restek Guard Column of $5 \mathrm{~m}$ was used, an analytical column Restek Rt-Q-BOND PLOT of $30 \mathrm{~m}$ and a particle trap column Restek PLOT of $2.5 \mathrm{~m}$; oven program $35{ }^{\circ} \mathrm{C}$ (2.25 min)-20 ${ }^{\circ} \mathrm{C} \mathrm{min}^{-1}-220{ }^{\circ} \mathrm{C}(5 \mathrm{~min})$; ion source temperature $200^{\circ} \mathrm{C}$, interface temperature $200{ }^{\circ} \mathrm{C}$, detector voltage $1.2 \mathrm{kV}$ and scan range $15-300 \mathrm{~m} / \mathrm{z}$.

\section{Results and discussion}

The XRD diffractograms of the two LNMO samples compared in this investigation are pictured in Fig. 1. Although the two crystallographic structures possible in LNMO are hard to distinguish from each other, the materials here show the typical signs of the disordered Fd-3m structure. The rock salt type impurity phase is present and there is no sign of any superstructure reflections; thus, there is no evidence of the ordered structure [11]. The $\mathrm{FePO}_{4}$ coating is not visible in the XRD diffractograms.

Figure 2 shows SEM images of the uncoated, and Fig. 3 shows SEM images of the coated LNMO sample. The particles are of a polygonal appearance, densely packed and based on an octahedral structure. The $\mathrm{FePO}_{4}$ coating is visible as a brighter layer in contrast to the darker base material. The coating is, however, not totally homogeneously distributed; uncoated particles are clearly visible.

Using EDX measurements, the coating was further investigated, see Fig. 4. The Fe is hard to discern as its peaks appear as shoulders beside the major Mn peaks. $\mathrm{P}$ with its peak at $2 \mathrm{keV}$, however, is a good indicator for the coating. The investigations show that the $\mathrm{FePO}_{4}$ is of a crystalline character, and confirm that the particles are not totally covered.

The particle size of the LNMO was measured by laser diffraction analysis, $\mathrm{d}(0.9)$ being $11.2 \mu \mathrm{m}$ and $\mathrm{d}(0.5)$ being $5.1 \mu \mathrm{m}$. The BET surface area of the samples was $1.2 \mathrm{~m}^{2} \mathrm{~g}^{-1}$ for the uncoated starting material and $10.0 \mathrm{~m}^{2} \mathrm{~g}^{-1}$ for the $\mathrm{FePO}_{4}$-coated LNMO, which was a surprisingly high value.

The electrochemical properties of the LNMO were improved by the $\mathrm{FePO}_{4}$ coating as shown in Fig. 5. Irreversible capacity losses in the first cycle were smaller, capacity retention improved and rate capability was enhanced.

Interestingly, the cyclovoltammograms of the coated LNMO material showed a suppressed current in the first cycle. However, after activation, the capacity is again more stable than that of the pristine LNMO, see Fig. 6.

The gas species which evolved due to reactions between the cathode and the electrolyte while running a $\mathrm{CV}$ are visualised in Fig. 7 for the uncoated LNMO and in Fig. 8 for the $\mathrm{FePO}_{4}{ }^{-}$ coated material.

Only the data of the first cycle are used; the species observed in high concentrations are summarised in the upper two diagrams, while the substances that were detected in low amounts can be found below. The diagrams on the left show the results when the voltage of the $\mathrm{CV}$ ran from OCV up to $5.0 \mathrm{~V}$; the diagrams on the right show the results when the potential was decreased from 5.0 down to $3.5 \mathrm{~V}$ again. On the $Y$-axis, the counts
Fig. 1 XRD diffraction pattern of the uncoated starting material and the LNMO sample coated with $\mathrm{FePO}_{4}$. The peaks indicated with asterisks $(*)$ are due to rock salt $\left(\mathrm{LiNiO}_{\mathrm{x}}\right)$ type impurities
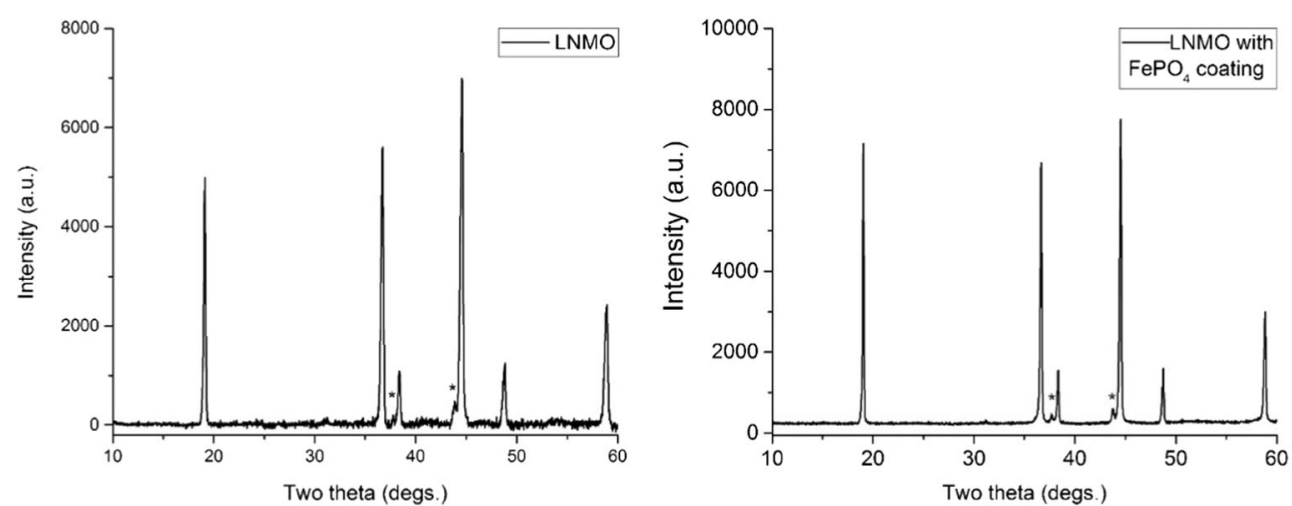
Fig. 2 SEM images of the investigated bare, uncoated LNMO samples at different magnifications
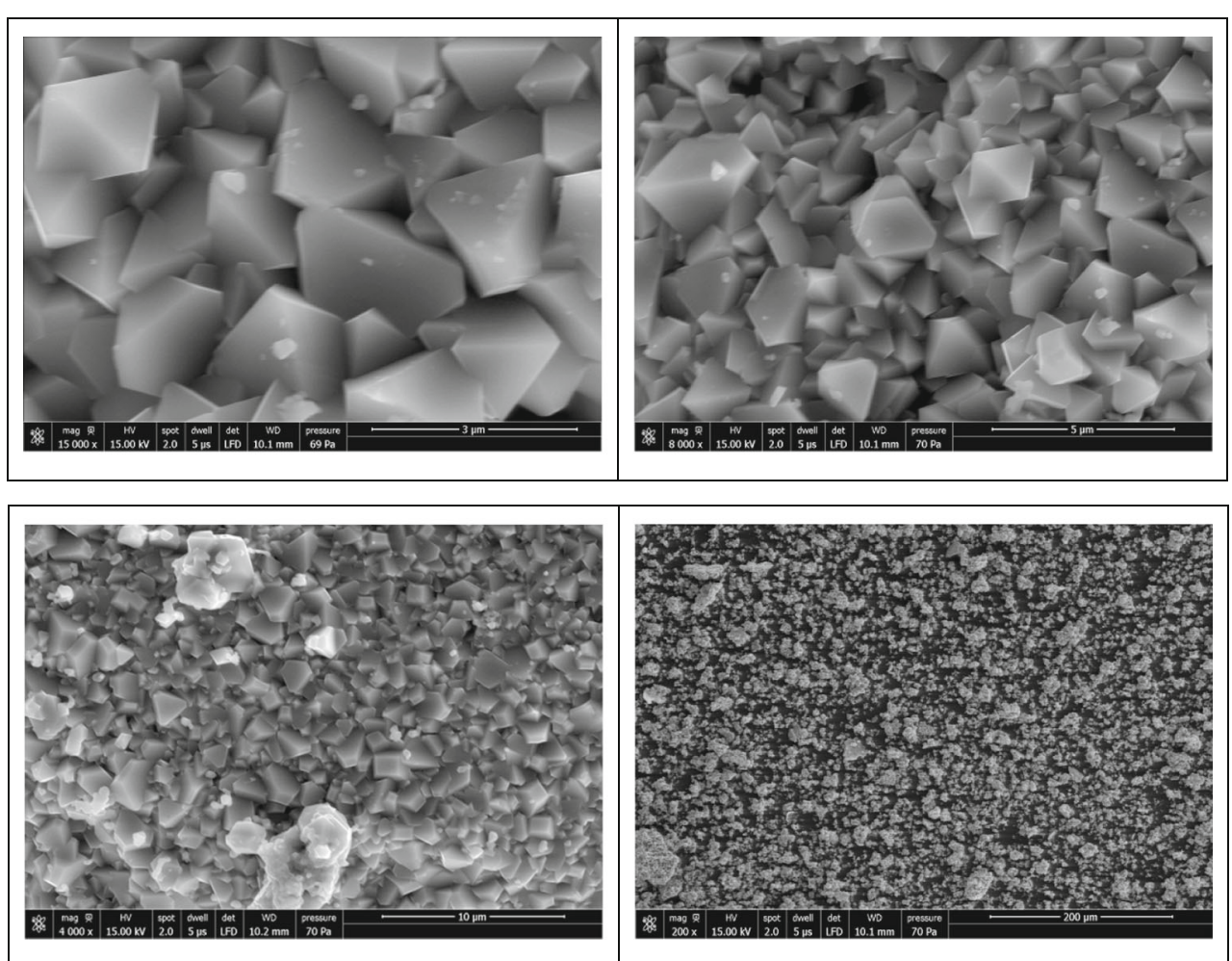

of the MS are listed, which can be considered as arbitrary units; on the $Z$-axis, the different species are enlisted.

EMC_-ethyl methyl carbonate $\left(M 104 \mathrm{~g} \mathrm{~mol}^{-1}, t\right.$ ret. $=11.67 \mathrm{~min})$, nitrogen $\left(M 28 \mathrm{~g} \mathrm{~mol}^{-1}, t_{\text {ret. }}=1.37 \mathrm{~min}\right)$, water
( $\left.M 18 \mathrm{~g} \mathrm{~mol}^{-1}, t_{\text {ret. }}=4.48 \mathrm{~min}\right), \mathrm{EC}$ - ethylene carbonate $(M$ $\left.88 \mathrm{~g} \mathrm{~mol}^{-1}, t_{\text {ret. }}=15.18 \mathrm{~min}\right)$ and DEC - diethyl carbonate $(M$ $118 \mathrm{~g} \mathrm{~mol}^{-1}, t_{\text {ret. }}=13.14 \mathrm{~min}$ ) were the species with the highest number of counts recorded by the MS.
Fig. 3 SEM images of the $\mathrm{FePO}_{4}$-coated LNMO samples at different magnifications
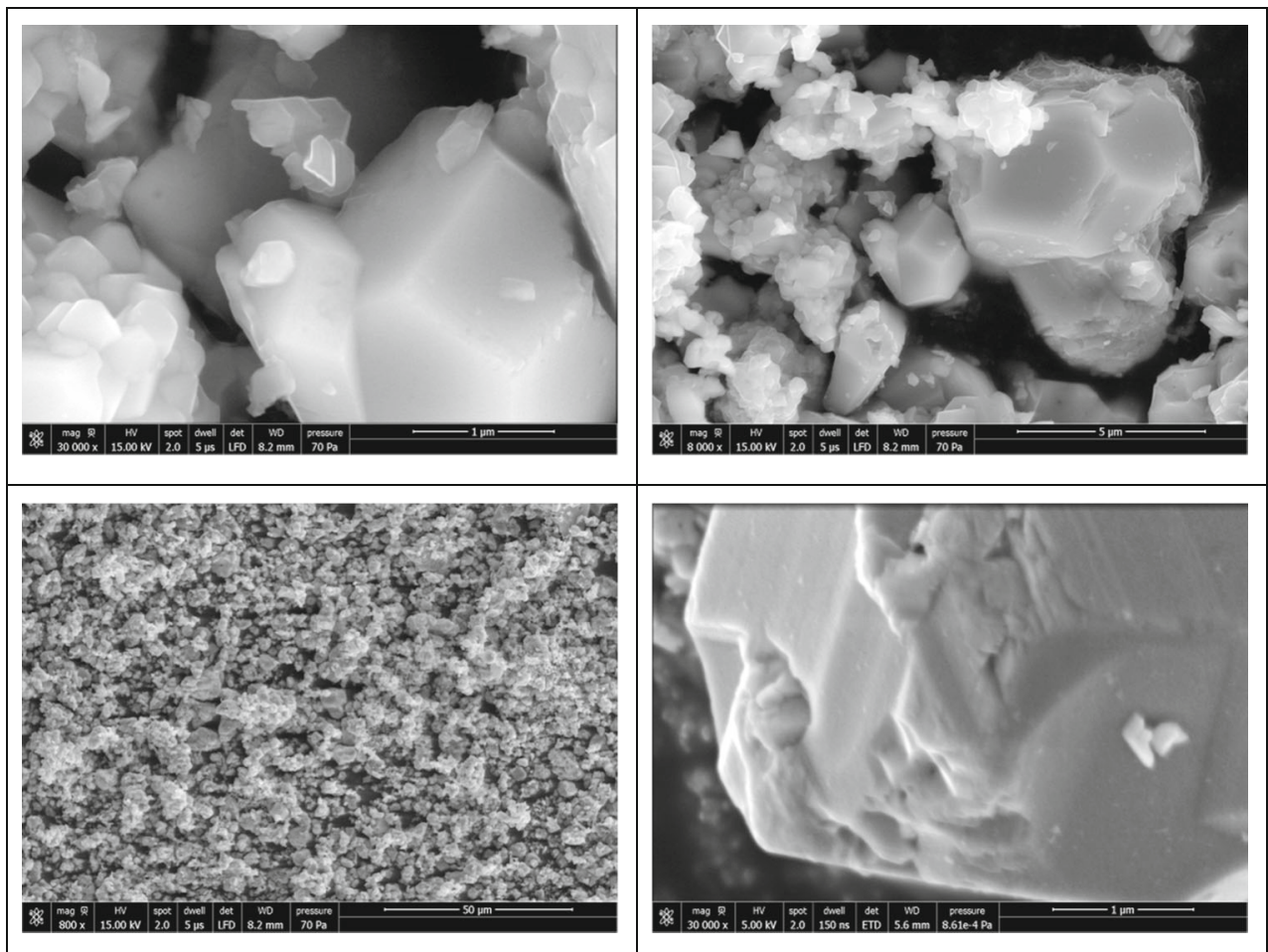
Fig. 4 SEM image (top) with EDX results, position 1 (middle) and 2 (bottom), of the $\mathrm{FePO}_{4}$ coated LNMO sample

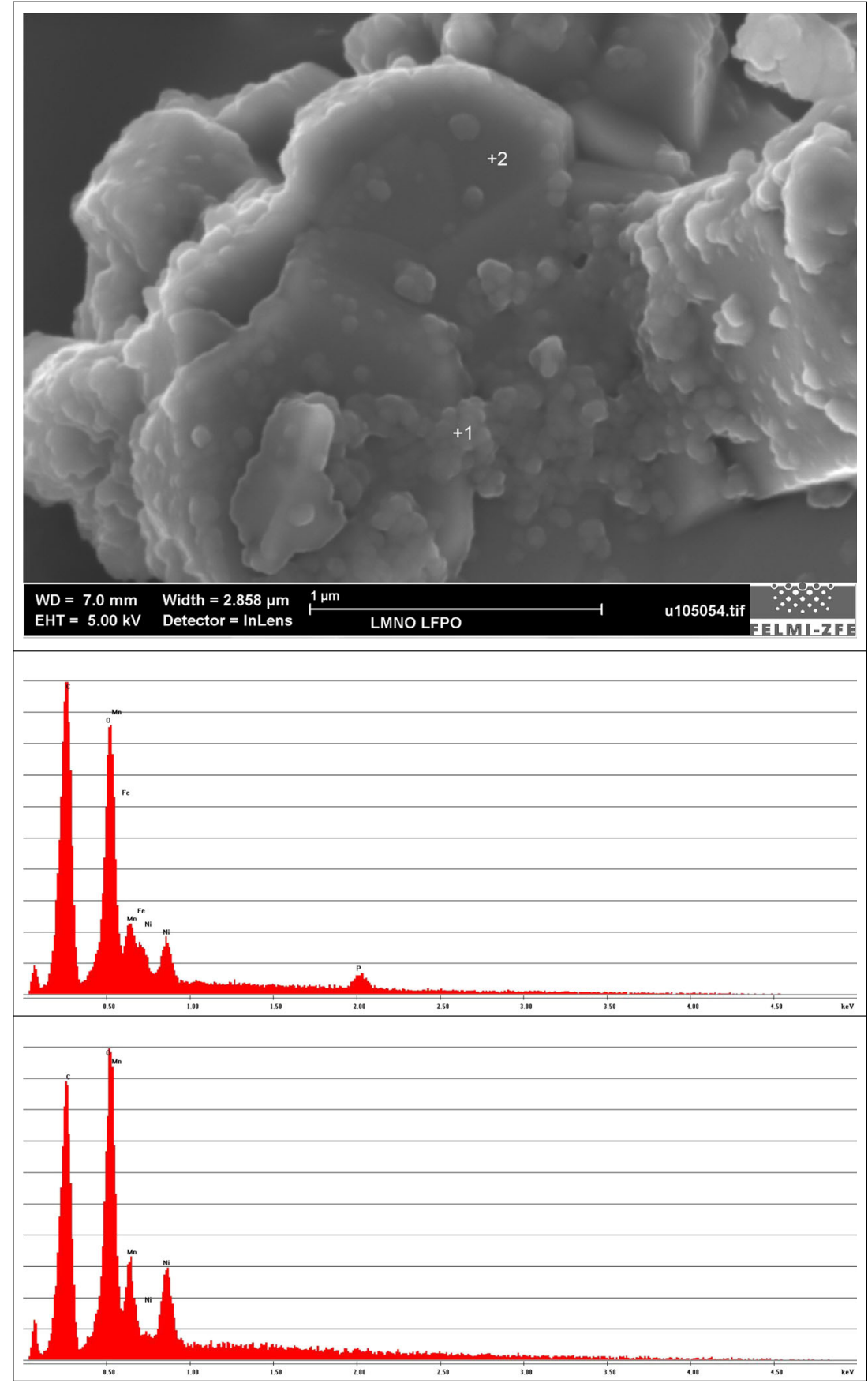

EMC, like ethanol $\left(M 46 \mathrm{~g} \mathrm{~mol}^{-1}, t_{\text {ret. }}=7.93 \mathrm{~min}\right)$ and acetone ( $M 58 \mathrm{~g} \mathrm{~mol}^{-1}, t_{\text {ret. }}=8.72 \mathrm{~min}$ ), was eliminated from the charts. EMC was eliminated as it was appearing in such concentrations it would have required another scale to be visualised; ethanol and acetone, because they were used for cleaning the cells and tubings and therefore can be considered as an experimental artefact. For this reason, the ethanol from the decomposition of the electrolyte could not be singled out in these experiments.

The nitrogen found represents the limitations of the experimental setup, as the sum of all leakages from the cells, from the connections and from the GC/MS. The amount of nitrogen in the diagrams is not directly comparable with the other substances, as the potential of the detector during the first minutes of each measurement has been reduced to protect the device from possible damage by an overload $(t=1-$ $1.75 \mathrm{~min}$ gain $=0.95$; from $1.75 \mathrm{~min}$ on gain $=1.62)$; thus, the nitrogen is only detected at approx. $30 \%$ of its real concentration.

The water content observed in the course of the experiments was surprisingly high. As nitrogen, water is an indicator of the 

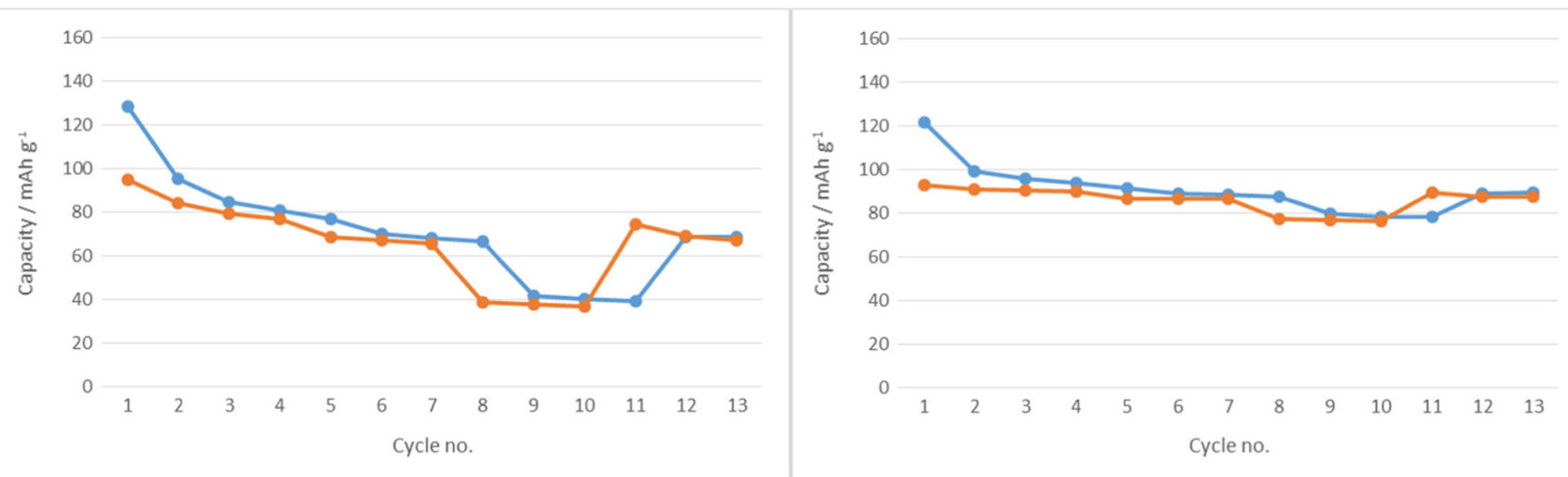

Fig. 5 Cycling performance at various C-rates of the uncoated pristine LNMO (left) and the $\mathrm{FePO}_{4}$-coated sample (right)

tightness of the cells and the whole experimental setup. Also, there are some water traces in the carrier gas $(\mathrm{He})$, and there are some residues from the cleaning of the cells. The electrolyte contains some traces of water, and the cathode and separator also add some residues. The contribution of each source of water cannot be estimated; water from other sources than the electrolyte is therefore a nuisance factor for the experiments which is to be eliminated as much as possible in the future.

Interestingly, the concentration of observed water was not constant, but showed a dependency on the cathode's potential. With rising potential, the water content recorded by the GC/MS decreased, and with decreasing potential, it slowly increased again afterwards. This indicates the occurrence of reactions which generate and consume water, the reactions depending on the cathode's potential.

The concentration of EC in the experiments showed a tendency towards increasing over time; according to the data, there is no dependency on the potential. Also, the type of cathode had no influence on the development of the EC concentration.

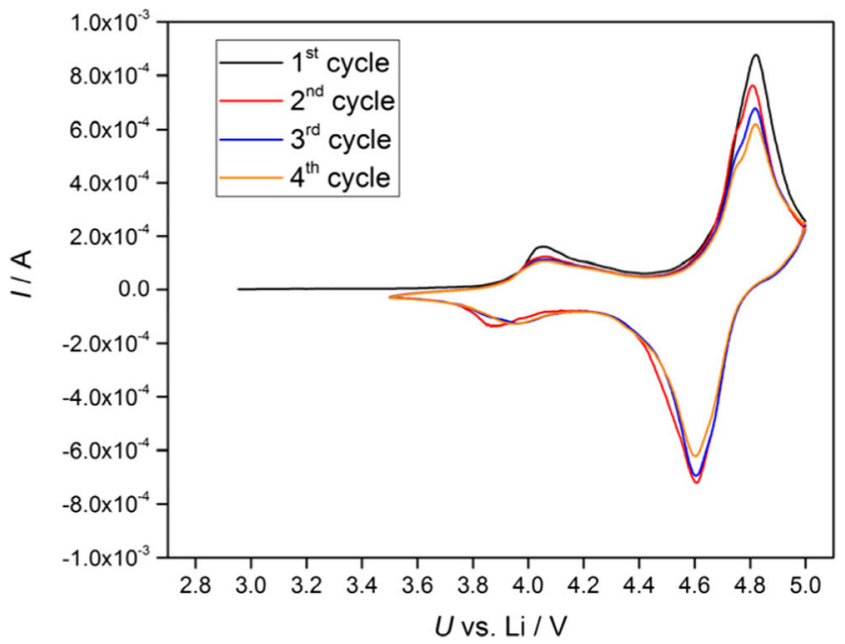

Of the species formed in the course of the experiments, DEC and DMC-dimethyl carbonate $\left(M 90 \mathrm{~g} \mathrm{~mol}^{-1}, t\right.$ ret. $=10.39 \mathrm{~min}$ - were present in the highest concentrations, apart from native electrolyte components or impurities.

Although it is well known that these species are formed by rearrangement of EMC [21], the mechanism of the cathode's influence on the concentration of the carbonates is not known yet, however.

$2 E M C \rightleftarrows D E C+D M C$

DEC and DMC were present with the same starting concentrations, independent of the LNMO used as cathode. With the uncoated LNMO, the concentration of both species decreased over time, following an exponential behaviour (which is due to the gas flow), with a small increase at high potentials overlaying this general decrease. The potential threshold from which onward the concentration of the carbonates began to rise again could not be estimated.

With the $\mathrm{FePO}_{4}$-coated LNMO, only the DMC concentration decreased over time; however, in a much more delayed manner, but the concentration of DEC remained constant at starting concentration.

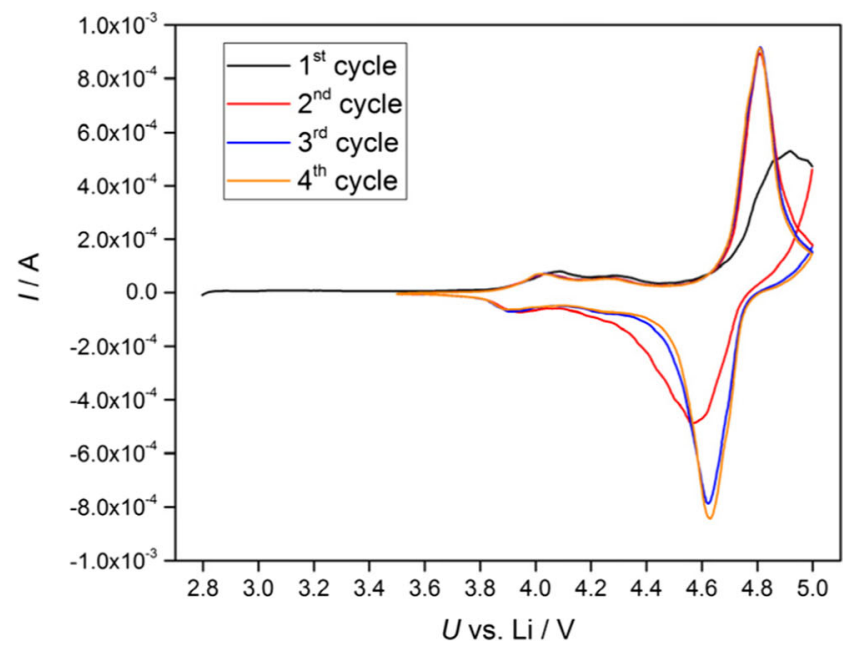

Fig. 6 Cycling voltammograms of the uncoated pristine LNMO (left) and the $\mathrm{FePO}_{4}$-coated sample (right) 

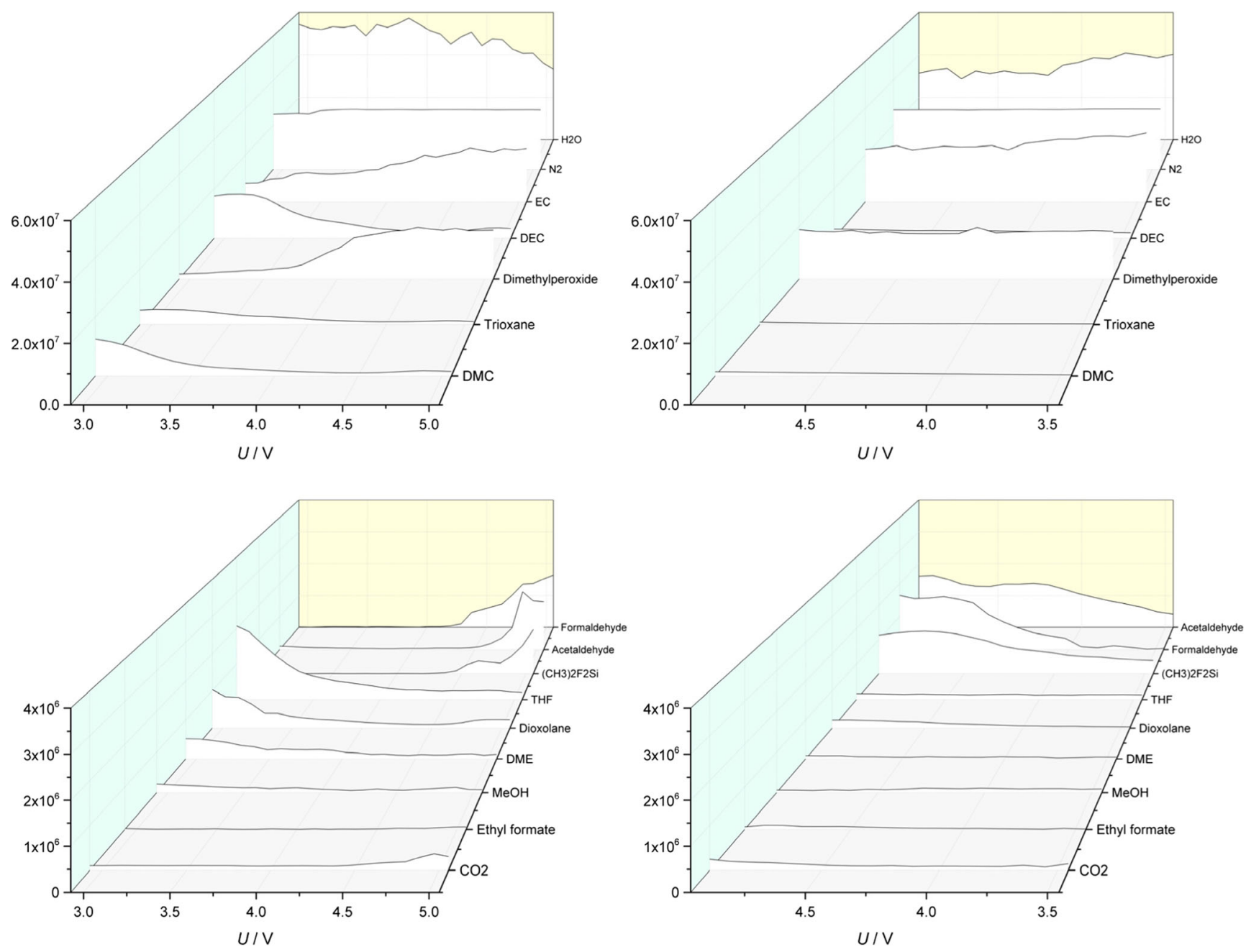

Fig. 7 The gas species observed while running a CV with the uncoated LNMO

The kinetic of formation and/or reduction of DEC and DMC seems to be influenced by the cathode material and the cathode's potential in a complex way.

The most interesting substance in the experiments with LNMO was the recorded dimethyl peroxide $\left(M 62 \mathrm{~g} \mathrm{~mol}^{-1}\right.$, $\left.t_{\text {ret. }}=13.09 \mathrm{~min}\right)$. However, its identification is not quite certain: the spectra, the most intense peaks being $\mathrm{m} / \mathrm{z} 29$ and 62 , has been assigned by the program by comparison with the database spectra to have a similarity of $81 \%$ with diethyl peroxide, and the matching with dimethyl peroxide was $79 \%$.

The reason why we assume it not to be diethyl peroxide is the total absence of the peak at $\mathrm{m} / \mathrm{z} 90$. Also 1,2-ethane diol was discussed, but this substance was not even taken into consideration by the program. Moreover, the retention time of the diol ought to be much shorter according to the reference spectra given by the columns manufacturer.

Several reaction pathways are possible; we postulate a reaction via the catalytic oxidation of DMC to dimethyl carbonate peroxide, with a subsequent elimination of $\mathrm{CO}_{2}$ being the likely pathway of dimethyl peroxide formation.

$$
\begin{aligned}
& \mathrm{CH}_{3}-\mathrm{O}-\mathrm{CO}-\mathrm{O}-\mathrm{CH}_{3}+{ }^{1} /{ }_{2} \mathrm{O}_{2} \text { (cat.LNMO) } \rightarrow \mathrm{CH}_{3} \\
& -\mathrm{O}-\mathrm{CO}-\mathrm{O}-\mathrm{O}-\mathrm{CH}_{3} \rightarrow \mathrm{CO}_{2}+\mathrm{CH}_{3}-\mathrm{O}-\mathrm{O}-\mathrm{CH}_{3}
\end{aligned}
$$

Other reactions are also theoretically possible, although the presence of radical type intermediates makes them not very likely, considering the number of possible rival side reactions.

$$
\begin{aligned}
& \mathrm{CH}_{3}-\mathrm{O}-\mathrm{CO}-\mathrm{O}-\mathrm{CH}_{2}-\mathrm{CH}_{3} \rightarrow \mathrm{CH}_{3}-\mathrm{O} \cdot+\mathrm{CO}_{2} \\
& +\mathrm{C}_{2} \mathrm{H}_{4}+\mathrm{H}^{+}+\mathrm{e}^{-} \mathrm{CH}_{3}-\mathrm{O}-\mathrm{CO}-\mathrm{O}-\mathrm{CH}_{2}-\mathrm{CH}_{3}+\mathrm{H}^{+} \\
& +\mathrm{e}^{-} \rightarrow \mathrm{CH}_{3}-\mathrm{O} \cdot+\mathrm{CO}_{2}+\mathrm{C}_{2} \mathrm{H}_{6} \mathrm{CH}_{3}-\mathrm{O}-\mathrm{CO}-\mathrm{O}-\mathrm{CH}_{2}-\mathrm{CH}_{3} \\
& +{ }^{1} /{ }_{2} \mathrm{O}_{2} \rightarrow \mathrm{CH}_{3}-\mathrm{O} \cdot+\mathrm{CO}_{2}+\mathrm{CHO}-\mathrm{CH}_{3}+\mathrm{H}^{+}+\mathrm{e}^{-} 2 \mathrm{CH}_{3} \\
& -\mathrm{O} \cdot \rightarrow \mathrm{CH}_{3}-\mathrm{O}-\mathrm{O}-\mathrm{CH}_{3}
\end{aligned}
$$

Interestingly, the peroxide was only present in minor amounts at OCV with the bare LNMO cathode, but the concentration then quickly increased; from around 4.25 Vonward, the concentration reached a plateau and remained constant afterwards. With the 

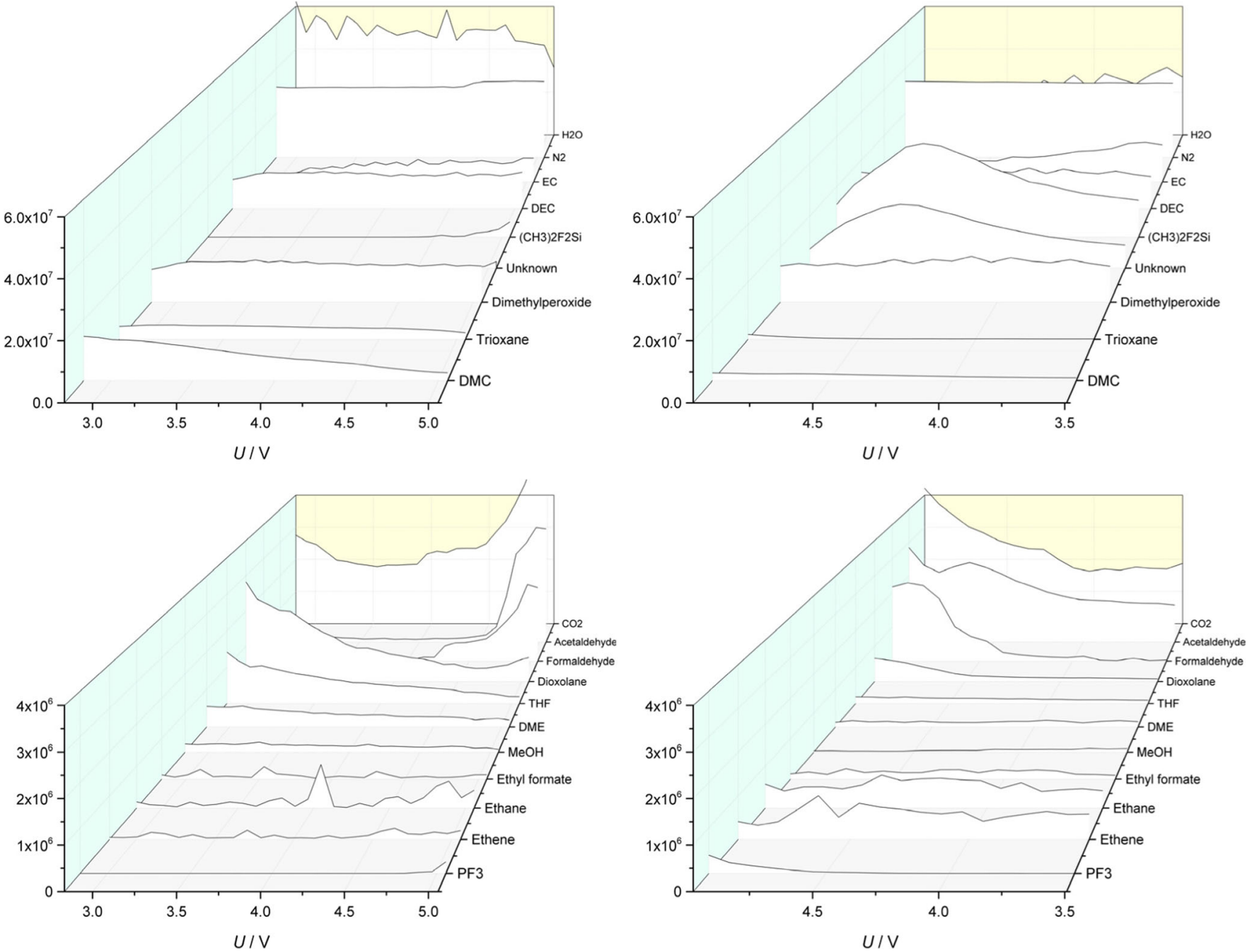

Fig. 8 The gas species observed while running a CV with the $\mathrm{FePO}_{4}$-coated $\mathrm{LNMO}$

$\mathrm{FePO}_{4}$-coated LNMO cathode, dimethyl peroxide was present from the $\mathrm{OCV}$ onward at full concentration, indicating that the $\mathrm{FePO}_{4}$ coating catalyses the generation of the peroxide already at $3 \mathrm{~V}$ and below. The plateau concentration of dimethyl peroxide was the same for the coated and bare LNMO.

Diethyl peroxide (as discussed above) and ethyl methyl peroxide, hypothetically existing analogues of dimethyl peroxide, could not be verified in any of the experiments run, indicating that the source of the peroxide is DMC only. There may be a sterical hindrance - EMC and DEC seem not to be sensitive to peroxide formation, assuming that the way of formation postulated above is the right one.

1,3,5-Trioxane $\left(M 90 \mathrm{~g} \mathrm{~mol}^{-1}, t_{\text {ret. }}=11.02 \mathrm{~min}\right)$ was already present at the same starting concentrations from OCV onwards in all experiments, independently of the cathode material used. With the bare LNMO cathode, the concentration then decreased exponentially over time, with a faint increase at high potentials overlaying this behaviour.

With the $\mathrm{FePO}_{4}$-coated LNMO cathode, the decrease in trioxane concentration was delayed.
Trioxane was very likely formed of formaldehyde, which also is the standard way of its synthesis; however, its origin from methanol is also possible. The fact that the trioxane was disappearing in the course of the experiments is interesting as the formaldehyde concentration was negligibly low at the beginning of the experiments and was strongly increasing at high potentials; the methanol amounts, though, were decreasing with higher potentials, see below.

The two substances which were showing the largest difference in response to the different LNMO samples were carbon dioxide $-\mathrm{CO}_{2}\left(M 44 \mathrm{~g} \mathrm{~mol}^{-1}, t_{\text {ret. }}=1.72 \mathrm{~min}\right)$ and $\left(\mathrm{CH}_{3}\right)_{2} \mathrm{~F}_{2} \mathrm{Si}$-dimethyl difluor silane $\left(M 96 \mathrm{~g} \mathrm{~mol}^{-1}\right.$, $t_{\text {ret. }}=7.30 \mathrm{~min}$ ).

The $\mathrm{CO}_{2}$ concentration with the bare LNMO remained on a constant level at first; it can be assumed this represents the "background noise" due to the system leakage described before. When the potential of the $\mathrm{CV}$ exceeded $4.3 \mathrm{~V}$, the measured $\mathrm{CO}_{2}$ content began to increase sharply, followed by a sharp decline when the potential, after reaching the vertex potential of $5.0 \mathrm{~V}$, was decreased again. Below $4.3 \mathrm{~V}$, the 
$\mathrm{CO}_{2}$ content again followed the plateau concentration known from the start.

In the detail visualisation of the $\mathrm{CO}_{2}$ data, two rates of kinetics are distinguishable; beyond $4.7 \mathrm{~V}$, the $\mathrm{CO}_{2}$ generation happens much faster than between 4.3 and $4.7 \mathrm{~V}$. However, this finding is already limited by the resolution of the experiments and can therefore only serve for qualitative interpretation.

With the $\mathrm{FePO}_{4}$-coated LNMO cathode, the $\mathrm{CO}_{2}$ concentration started on a much higher level than with the bare LNMO cathode; this is true both absolutely and relative to the nitrogen levels. The $\mathrm{CO}_{2}$ concentration decreased slightly at first, and then it increased again with increasing cathode potential. The data of the potential-induced $\mathrm{CO}_{2}$ increase and decrease are not as distinct as before; one may infer two different kinetics. The potentials where the $\mathrm{CO}_{2}$ kinetics changed are likely to be around 4.0 and again $4.3 \mathrm{~V}$.

The immediate response of the $\mathrm{CO}_{2}$ concentration showed on the increase and decrease of the cathodes' potential is noteworthy - the $\mathrm{CO}_{2}$ amounts measured showed no delay, unlike most other substances in these experiments, Fig. 9.

$\left(\mathrm{CH}_{3}\right)_{2} \mathrm{~F}_{2} \mathrm{Si}$ is a degradation product from the GC's column due to the formation of HF in the course of the experiments. Thus, it can be considered as a direct indicator of HF. When using the $\mathrm{FePO}_{4}$-coated LNMO as cathode, much more $\left(\mathrm{CH}_{3}\right)_{2} \mathrm{~F}_{2} \mathrm{Si}$ was detected-semi-quantitatively estimated about 20 times more than with the bare LNMO cathode.

While the HF generation is of great interest, the onset of the reaction could not be determined exactly in these experiments due to the delay with which the substance was appearing in the records. One could guess at 4.4 to $4.5 \mathrm{~V}$, which is not more accurate than what is already known from literature.

Trimethyl fluor silane- $\left(\mathrm{CH}_{3}\right)_{3} \mathrm{FSi}\left(M 92 \mathrm{~g} \mathrm{~mol}^{-1}, t\right.$ ret. $=8.71 \mathrm{~min})$, like $\left(\mathrm{CH}_{3}\right)_{2} \mathrm{~F}_{2} \mathrm{Si}$ a degradation product from the GC's column, was also detected in the experiments, but could not be analysed due to the presence of acetone residues. The latter unfortunately caused a much stronger signal which overlaid the silane's ones.

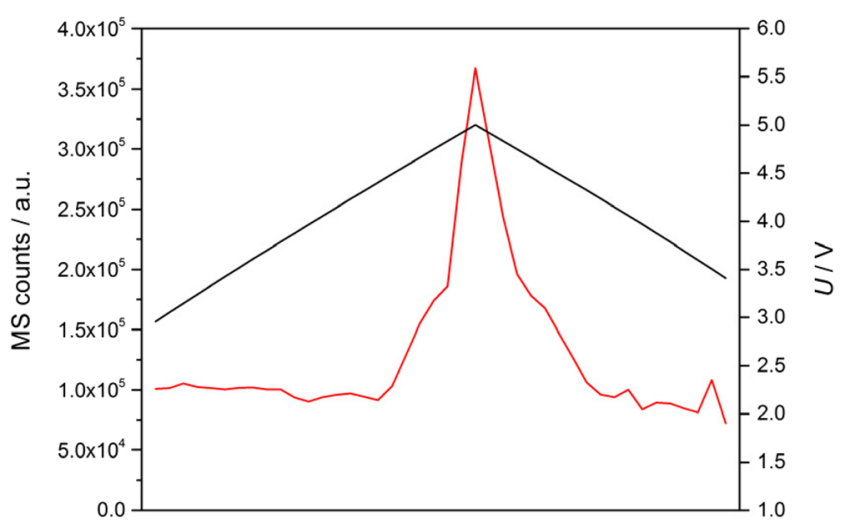

Fig. 9 Progress of the $\mathrm{CO}_{2}$ concentration versus the CV's potential from an experiment with a bare LNMO cathode
With the $\mathrm{FePO}_{4}$-coated $\mathrm{LNMO}$ cathode, we also found an unknown remaining substance $\left(M 155 \mathrm{~g} \mathrm{~mol}^{-1}\right.$ (?), $t$ ret. $=11.97 \mathrm{~min}$ ) which was not present in the experiments with the bare LNMO cathode. The substance showed a very similar behaviour to $\left(\mathrm{CH}_{3}\right)_{2} \mathrm{~F}_{2} \mathrm{Si}$. Therefore, we suspect it to be an HFinduced degradation product of the GC's column; its MS spectra showed only a singular, dominant peak of $\mathrm{m} / \mathrm{z} 155$.

Triethyl phosphate has recently been described as a degradation product of $\mathrm{LiPF}_{6}$. It also has a very typical peak of $\mathrm{m} / \mathrm{z} 155$, but the MS spectra given do not fit ours [22]. Another interpretation might be tert-butyl dimethyl silyl methyl phosphonofluoridate; however, we could not prove this one, either [23].

Formaldehyde $\left(M 30 \mathrm{~g} \mathrm{~mol}^{-1}, t_{\text {ret. }}=5.88 \mathrm{~min}\right)$ was found in the experiments with both cathode materials. The substance was not present at the beginning of the experiments. First notable amounts were detected from $4.2 \mathrm{~V}$ on, but since there is a delay which has to be considered, the real reaction onset can be supposed at around $4.0 \mathrm{~V}$. The concentration then increased with the potential and decreased afterwards again, approximating zero.

Noteworthy in the progress of the development of the formaldehyde concentration is a shoulder that can be recognised, distinct when the potential is increased, more blurred when the potential is reduced, indicating there might be two reactions leading to formaldehyde or one reaction, but accelerated at certain potentials.

This character of the concentration curves over the cathode's potential appears to be independent of the cathode material; however, the $\mathrm{FePO}_{4}$ coating seems to have promoted the degradation reaction(s), since there is more formaldehyde than in the corresponding experiments with the bare LNMO cathode.

The primary reaction generating formaldehyde is almost certainly the oxidation of methanol; the second reaction which might have occurred remains unknown.

Acetaldehyde $\left(M 44 \mathrm{~g} \mathrm{~mol}^{-1}, t_{\text {ret. }}=6.55 \mathrm{~min}\right)$ was also found with both cathode materials. There were some very small amounts present from OCV onward, but the majority of the substance was generated at high cathode potentials. The onset of the degradation reaction leading to acetaldehyde cannot be estimated as the substance appeared with a long delay.

Unlike with formaldehyde, there was no evidence of a second reaction, and due to the delay in time, the concentration of acetaldehyde did not go down to zero when the potential was decreased in the $\mathrm{CV}$. The $\mathrm{FePO}_{4}$ coating again promoted the degradation reaction; the acetaldehyde concentration was about two times higher than with the bare LNMO cathode.

The oxidation of ethanol is very likely the dominant source of acetaldehyde.

1,3-Dioxolane $\left(M 74 \mathrm{~g} \mathrm{~mol}^{-1}, t_{\text {ret. }}=9.87 \mathrm{~min}\right)$ was present already at OCV in the experiments, the concentration decreasing exponentially with time. With an onset at around $4.5 \mathrm{~V}$, a 
slight increase was overlying the generally decreasing concentration profile.

This behaviour was the same for both cathode materials, but with the $\mathrm{FePO}_{4}$-coated LNMO, the 1,3-dioxolane followed a two-time higher concentration profile.

Although frequently used as electrolyte solvent, 1,3dioxolane has to the best of our knowledge not been described as a decomposition product so far $[1,24,25]$. The chemistry of the compound and its presence already at the beginning of the experiments indicate an origin from a reaction on the lithium anode; however, the observed dependency on high cathode potentials is strange. A mechanism based on a reduction and a subsequent nucleophilic reaction as described by G. Gachot et al. [26] is proposed.

$$
\begin{aligned}
\mathrm{EC} & +\mathrm{e}^{-} \rightarrow \mathrm{O}^{-}-\mathrm{CH}_{2}-\mathrm{CH}_{2}-\mathrm{O}-\mathrm{C} . \\
& =\mathrm{OO}^{-}-\mathrm{CH}_{2}-\mathrm{CH}_{2}-\mathrm{O}-\mathrm{C} . \\
& =\mathrm{O}+\mathrm{CH}_{2} \mathrm{O} \rightarrow 1,3-\text { dioxolane }+\mathrm{CO}_{2}+\mathrm{e}^{-}
\end{aligned}
$$

The EC ring is opened by a reduction, and the intermediate substance, or the diol resulting after the addition of water and the removal of $\mathrm{CO}_{2}$, reacts with formaldehyde. Via a hemiacetal, 1,3-dioxolane is finally formed. The reactions may or may not be catalysed by the lithium ions via lithium alkoxides or traces of HF.

The observed absence of formaldehyde at $\mathrm{OCV}$, in contrast to the present acetaldehyde, could be explained by this reaction which consumes all formaldehyde formed at the cathode. When at high potentials, formaldehyde is then generated in higher quantities, and the dioxolane concentration again increases for a while, until the formaldehyde supply runs out due to the decreasing cathode potential. All these mechanisms are dominated by the experimental gas flow which causes the observed 1,3-dioxolane decrease over time, see Fig. 10.

THF, tetrahydrofuran $\left(M 72 \mathrm{~g} \mathrm{~mol}^{-1}, t_{\text {ret. }}=10.34 \mathrm{~min}\right)$, was also present from $\mathrm{OCV}$ on, its concentration decreasing with time. A dependency on the cathode's potential as for the 1,3-

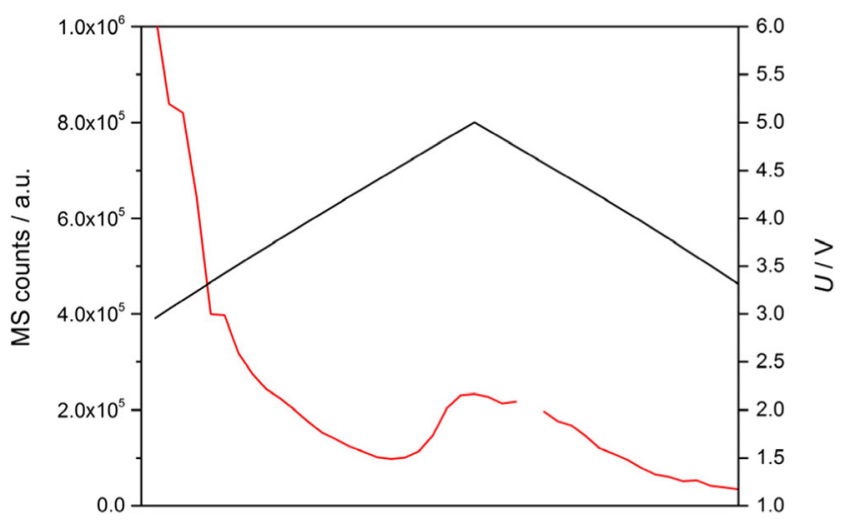

Fig. 10 Progress of the 1,3-dioxolane concentration versus the CV's potential from an experiment with a bare LNMO cathode dioxolane above could neither be confirmed nor refuted with the available data. Although the illustrated experiments are not showing it clearly, the concentration can be considered the same for both cathode materials.

Although at times used as electrolyte component [1, 27], THF has also been mentioned as degradation product found in lithium-ion electrolytes [23]. To the best of our knowledge, no reaction pathways explaining its presence have been published yet.

The properties observed in the course of the experiments indicate formation on the lithium anode. The formulation of a reaction of a $\mathrm{C} 4$ compound is tricky, as there were no starting materials based on $\mathrm{C} 4$ units. As no $\mathrm{C} 3$ compounds were found in the measurements, assuming an EC origin seems more logical than a reaction based on one of the linear carbonates EMC (DEC or DMC), from which C3-based substances could also be expected.

For the further postulation of a mechanism, it is necessary to elaborate at some length. The SEI formed on the anode surface has been found to consist of a dense inorganic layer and a second more porous organic layer, the latter mainly consisting of polyethylene glycol oligomers formed of EC molecules (or polypropylene glycol when PC is used). Several glycol units, differing by their end groups, are condensed together. Carbonate, alkoxyl, hydroxyl and phosphate groups have been reported, see Fig. 11 [28-30].

Based on the end groups, a classification has been established, and different formation mechanisms have been published. A transesterification was proposed, a start from alkoxides has been described and a $\mathrm{PF}_{5}$ (Lewis acid) supported mechanism has also been published on [30-33].

On the basis of these reaction mechanisms, we propose a reaction in which $\mathrm{a} \mathrm{CO}_{3}{ }^{-2}$ ion is eliminated instead of $\mathrm{CO}_{2}$ by a rearrangement, lithium ions likely stabilising the carbonate ion formed, see Fig. 12.

The absence of $\mathrm{C} 6$ components indicates that the $\mathrm{C} 4$ unit will quickly undergo a ring closing reaction to form furan, or that THF is rather stable and does not further participate in other reactions. For the nature of the end groups, it can be suspected that they are of a rather small size.

Methanol ( $\left.M 32 \mathrm{~g} \mathrm{~mol}^{-1}, t_{\text {ret. }}=6.32 \mathrm{~min}\right)$ was present in the experiments in very small amounts from OCV on the concentration decreasing both with time and with rising cathode potential. With decreasing potential, the concentration began to rise again faintly, indicating a methanol consuming reaction at higher potentials, and that there is a continuous supply by a

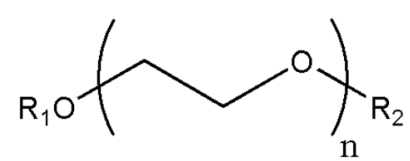

Fig. 11 General formula of the polyethylene-based oligomers found in an SEI [30] 


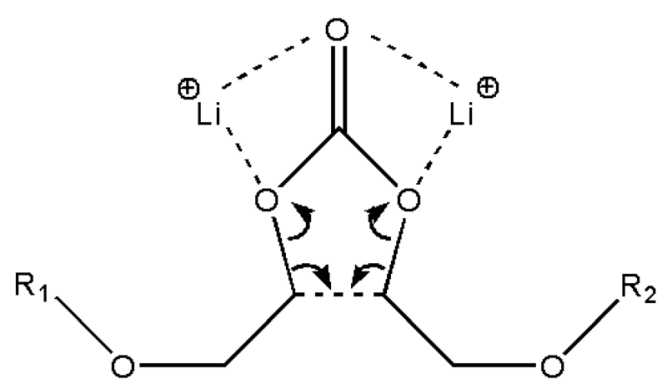

Fig. 12 Proposed reaction for the formation of a $\mathrm{C} 4$ unit by two ethylene glycol units by a rearrangement and elimination of $\mathrm{a} \mathrm{CO}_{3}{ }^{-2}$ ion

second reaction on a very small scale. The concentration and its profile were the same for both cathode materials.

The potential dependency is likely explained with an oxidation of methanol to formaldehyde; while the supplying reaction, which also explains the methanol present at the start of the experiments, is the hydrolysis of EMC (DMC), catalysed by $\mathrm{HF}$ and traces of water.

Ethyl formate $\left(M 74 \mathrm{~g} \mathrm{~mol}^{-1}, t_{\text {ret. }}=9.11 \mathrm{~min}\right)$ was generated in very small amounts at higher potentials, though the substance was appearing with a delay; therefore, the onset potential of the formation reaction cannot be estimated. The $\mathrm{FePO}_{4}$ coating was catalysing the reaction, so there was more ethyl formate with this cathode material than with the other.

The mechanism leading to formation of this substance remains unclear. An anodic reaction pathway has been proposed by Gachot et al. [26]. However, an anodic reaction is not likely for these experiments, as there is a dependency on the cathode potential and another one on the cathode material. A formation from ethanol, or its lithium alkoxide reacting with formaldehyde, the resulting hemiacetal then further being oxidised, could explain the formation of ethyl formate.

$$
\begin{aligned}
& \mathrm{CH}_{3}-\mathrm{CH}_{2}-\mathrm{OH}+\mathrm{CH}_{2} \mathrm{O} \rightarrow \mathrm{CH}_{3}-\mathrm{CH}_{2}-\mathrm{O} \\
& \quad-\mathrm{CH}_{2}-\mathrm{OH} \rightarrow \mathrm{CH}_{3}-\mathrm{CH}_{2}-\mathrm{O}-\mathrm{CHO}+2 \mathrm{e}^{-}+2 \mathrm{H}^{+}
\end{aligned}
$$

This reaction pathway, however, is not quite satisfactory as no methyl formate was found in any of the experiments; on the other hand, ethanol, as explained above, was present in much higher amounts than methanol. We would also have expected some ethyl acetate and methyl acetate; however, only the latter was found at least in traces.

1,2-Dimethoxy ethane, DME $\left(M 90 \mathrm{~g} \mathrm{~mol}^{-1}, t_{\text {ret. }}=11.18 \mathrm{~min}\right)$, behaved similarly to THF. It was present from OCV on the concentration decreasing over time. There seems to have been no dependency on the cathode potential nor on the cathode material used.

The lack of dependencies and the presence already at the start of the experiments indicate an origin not based on the cathode side. An anodic reaction on the lithium side is obvious; a convincing reaction mechanism has been described by Gachot et al. [26].
Surprisingly, no ethane diol and also no 1,4-dioxane were found in any of the experiments run with LNMO samples. We suspect that ethane diol is only an intermediate and therefore is consumed by other reactions rather quickly. 1,4-Dioxane has been described as an anodic product; it remains unclear whether this substance has not been formed at all or whether the compound has been oxidised on the cathode-which would raise the question why it should be less stable than 1,3-dioxolane or 1,3,5-trioxane.

Phosphor trifluoride, $\mathrm{PF}_{3}\left(M 88 \mathrm{~g} \mathrm{~mol}^{-1}, t_{\text {ret. }}=2.10 \mathrm{~min}\right)$, could only be detected in very small amounts in combination with the $\mathrm{FePO}_{4}$-coated LNMO and at very high potentials. The onset of the degradation reaction leading to $\mathrm{PF}_{3}$ is estimated to occur at 4.5 to $4.6 \mathrm{~V}$.

The formulation of a reaction explaining $\mathrm{PF}_{3}$ as an oxidative reaction product is difficult; one could assume it is the side product of a degradation reaction of $\mathrm{LiPF}_{6}$ and the $\mathrm{FePO}_{4}$ coating.

Ethane $\left(M 30 \mathrm{~g} \mathrm{~mol}^{-1}, t_{\text {ret. }}=2.78 \mathrm{~min}\right)$ and ethene $(M$ $28 \mathrm{~g} \mathrm{~mol}^{-1}, t_{\text {ret. }}=2.28 \mathrm{~min}$ ) could only be detected in very small amounts and after the cathode reached high potentials. The concentration increased with a long delay; the $\mathrm{FePO}_{4}$ coated material generated about three times more of these substances than the bare LNMO cathode.

In literature, the hydrocarbons have been said to originate from reductive mechanisms or oxidative degradation mechanisms $[20,34,35]$; in our experiments, the latter ought to apply.

Traces of methyl acetate $\left(M 74 \mathrm{~g} \mathrm{~mol}^{-1}, t_{\text {ret. }}=9.17 \mathrm{~min}\right)$ and 2-methyl-1,3-dioxolane $\left(M 88 \mathrm{~g} \mathrm{~mol}^{-1}, t_{\text {ret. }}=10.86 \mathrm{~min}\right)$ could be detected in some experiments, though due to the small amounts, it is not possible to determine a dependency of these substances' formation on the cathode's potential or material.

A good explanation for the reductive formation of these substances has again been given by Gachot et al. [26].

\section{Summary and conclusions}

Two LNMO samples, one bare and one with a coating of $\mathrm{FePO}_{4}$, were electrochemically characterised, and the degradation products formed during the running of a cyclovoltammetric experiment were investigated with a $\mathrm{GC} /$ MS combination. The development of the concentrations was determined online and visualised for better evaluation.

Using $1 M \mathrm{LiPF}_{6}, \mathrm{EC}: \mathrm{EMC}=3: 7,2 \% \mathrm{FEC}$ as electrolyte, carbon dioxide, dimethyl peroxide, 1,3,5-trioxane, 1,2dimethoxy ethane, acetaldehyde, THF, dimethyl difluor silane and other compounds were found. Where degradation pathways were unknown, new ones were suggested.

The degradation products found in the course of the experiments with the LNMO samples were in part surprising; 
however, it is almost more surprising how many of the degradation products described in the relevant literature did not appear in our measuring campaigns. The cathode material seems to have a significant influence on electrolyte decomposition.

Measuring the development of the concentration of the decomposition products over time and correlating the concentrations with the CV's potential though has been found to give valuable insights into the reactions occurring.

Acknowledgements The measurements and results described in this paper were generated in the course of the eCaiman project which was generously co-funded under the H2020 framework by the European Union.

Open Access This article is distributed under the terms of the Creative Commons Attribution 4.0 International License (http:// creativecommons.org/licenses/by/4.0/), which permits unrestricted use, distribution, and reproduction in any medium, provided you give appropriate credit to the original author(s) and the source, provide a link to the Creative Commons license, and indicate if changes were made.

\section{References}

1. Daniel C, Besenhard JO (eds) (2011) Handbook of battery materials $2^{\text {nd }}$ edition. Wiley-VCH, Weinheim

2. Thackeray MM, Johnson CS, Vaughey JT, Li N, Hackney SA (2005) Advances in manganese-oxide "composite" electrodes for lithium-ion batteries. J Mater Chem 15:2257-2267

3. Croy JR, Park JS, Shin Y, Yonemoto BT, Balasubramanian M, Long BR, Ren Y, Thackeray MM (2016) Prospects for spinel-stabilized, high-capacity lithium-ion battery cathodes. J Power Sources 334:213-220

4. Padhi AK, Nanjundaswamy KS, Goodenough JB (1997) Phosphoolivines as positive-electrode materials for rechargeable lithium batteries. J Electrochem Soc 144:1188-1194

5. Amine K, Yasuda H, Yamachi M (2000) Olivine $\mathrm{LiCoPO}_{4}$ as $4.8 \mathrm{~V}$ electrode material for lithium batteries. Electrochem Solid-State Lett 3:178-179

6. Axmann P, Stinner C (2009) Positive electrode: high-voltage materials. In: Garche J, Dyer C, Moseley P, Ogumi Z, Rand D, Scrosati B (eds) Encyclopedia of electrochemical power sources, vol 5. Elsevier, Amsterdam Boston Heidelberg London New York Oxford Paris San Diego San Francisco Singapore Sydney Tokyo, pp 237-242

7. Zhong Q, Bonakdarpour A, Zhang M, Gao Y, Dahn JR (1997) Synthesis and electrochemistry of $\mathrm{LiNi}_{\mathrm{x}} \mathrm{Mn}_{2-\mathrm{x}} \mathrm{O}_{4}$. J Electrochem Soc 144:205-213

8. Ohzuku T, Takeda S, Iwanaga M (1999) Solid-state redox potentials for $\mathrm{Li}\left[\mathrm{Me}_{1 / 2} \mathrm{Mn}_{3 / 2}\right] \mathrm{O}_{4}$ (Me: 3d-transition metal) having spinelframework structures: a series of 5 volt materials for advanced lithium-ion batteries. J Power Sources 81-82:90-94

9. Amine K, Tukamoto H, Yasuda H, Fujita Y (1997) Preparation and electrochemical investigation of $\mathrm{LiMn}_{2}{ }_{\mathrm{x}} \mathrm{Me}_{\mathrm{x}} \mathrm{O}_{4}$ (Me: $\mathrm{Ni}, \mathrm{Fe}$, and $\mathrm{x}=0.5,1)$ cathode materials for secondary lithium batteries. $\mathrm{J}$ Power Sources 68:604-608

10. Yi T-F, Mei J, Zhu Y-R (2016) Key strategies for enhancing the cycling stability and rate capacity of $\mathrm{LiNi}_{0.5} \mathrm{Mn}_{1.5} \mathrm{O}_{4}$ as highvoltage cathode materials for high power lithium-ion batteries. $\mathrm{J}$ Power Sources 316:85-105
11. Axmann P, Gabrielli G, Wohlfahrt-Mehrens M (2016) Tailoring high-voltage and high-performance $\mathrm{LiNi}_{0.5} \mathrm{Mn}_{1.5} \mathrm{O}_{4}$ cathode material for high energy lithium-ion batteries. J Power Sources 301:151159

12. Choi N-S, Han J-G, Ha S-Y, Park I, Back C-K (2015) Recent advances in the electrolytes for interfacial stability of high-voltage cathodes in lithium-ion batteries. RSC Adv 5:2732-2748

13. Xu M, Tsiouvaras N, Garsuch A, Gasteiger HA, Lucht BL (2014) Generation of cathode passivation films via oxidation of lithium bis (oxalate) borate on high voltage spinel $\left(\mathrm{LiNi}_{0.5} \mathrm{Mn}_{1.5} \mathrm{O}_{4}\right)$. J Phys Chem 118:7363-7368

14. Wang H, Rus E, Sakuraba T, Kikuchi J, Kiya Y, Abruña HD (2014) $\mathrm{CO}_{2}$ and $\mathrm{O}_{2}$ evolution at high voltage cathode materials of $\mathrm{Li}$-ion batteries: a differential electrochemical mass spectrometry study. Anal Chem 86:6197-6201

15. Kulova TL, Skundin AM (2016) High-voltage materials for positive electrodes of lithium ion batteries (review). RUSS J ELECTROCHEM+ 52:501:524

16. Qian Y, Schultz C, Niehoff P, Schwieters T, Nowak S, Schappacher FM, Winter M (2016) Investigations on the electrochemical decomposition of the electrolyte additive vinylene carbonate in $\mathrm{Li}$ metal half cells and lithium ion full cells. J Power Sources 332:60-71

17. Xia J, Dahn JR (2016) Improving sulfolane-based electrolyte for high voltage Li-ion cells with electrolyte additives. J Power Sources 324:704-711

18. Imholt L, Röser S, Börner M, Streipert B, Rad BR, Winter M, Cekic-Laskovica I (2017) Trimethylsiloxy based metal complexes as electrolyte additives for high voltage application in lithium ion cells. Electrochim Acta 235:332-339

19. Yong T, Zhang L, Wang J, Mai Y, Yan X, Zhao X (2016) Novel choline-based ionic liquids as safe electrolytes for high-voltage lithium-ion batteries. J Power Sources 328:397-404

20. Gachot G, Ribiere P, Mathiron D, Grugeon S, Armand M, Leriche J-B, Pilard S, Laruelle S (2011) Gas chromatography/mass spectrometry as a suitable tool for the Li-ion battery electrolyte degradation mechanisms study. Anal Chem 83:478-485

21. Takeuchi ES, Gan H, Palazzo M, Leising RA, Davis SM (1997) Anode passivation and electrolyte solvent disproportionation: mechanism of ester exchange reaction in lithiumion batteries. J Electrochem Soc 144:1944-1948

22. Weber W, Kraft V, Grützke M, Wagner R, Winter M, Nowak S (2015) Identification of alkylated phosphates by gas chromatography-mass spectrometric investigations with different ionization principles of a thermally aged commercial lithium ion battery electrolyte. J Chromatogr A 1394:128-136

23. Amon A (2014) Gas evolution from lithium ion batteries studied insitu by coupled GC/MS-FTIR. Master Thesis Vienna University, Vienna

24. Pang C, Ding F, Sun W, Liu J, Hao M, Wang Y, Liu X, Xu Q (2015) A novel dimethyl sulfoxide/1,3-dioxolane based electrolyte for lithium/carbon fluorides batteries with a high discharge voltage plateau. Electrochim Acta 174:230-237

25. Suo L, Hu Y-S, Li H, Armand M, Chen L (2013) A new class of solvent-in-salt electrolyte for high-energy rechargeable metallic lithium batteries. Nat Commun 4:1481

26. Gachot G, Grugeon S, Eshetu GG, Mathiron D, Ribière P, Armand M, Laruelle S (2012) Thermal behaviour of the lithiated-graphite/ electrolyte interface through GC/MS analysis. Electrochim Acta 83: 402-409

27. Xu W, Wang J, Ding F, Chen X, Nasybulin E, Zhang Y, Zhang J-G (2014) Lithium metal anodes for rechargeable batteries. Energy Environ Sci 7:513-537

28. Edström K, Herstedt M, Abraham DP (2006) A new look at the solid electrolyte interphase on graphite anodes in $\mathrm{Li}$-ion batteries. $\mathrm{J}$ Power Sources 153:380-384 
29. Laruelle S, Pilard S, Guenot P, Grugeon S, Tarascon J-M (2004) Identification of Li-based electrolyte degradation products through DEI and ESI high-resolution mass spectrometry. J Electrochem Soc 151:A1202-A1209

30. Gachot G, Grugeon S, Armand M, Pilard S, Guenot P, Tarascon JM, Laruelle S (2008) Deciphering the multi-step degradation mechanisms of carbonate-based electrolyte in Li batteries. J Power Sources 178:409-421

31. Yoshida H, Fukunaga T, Hazama T, Terasaki M, Mizutani M, Yamachi M (1997) Degradation mechanism of alkyl carbonate solvents used in lithium-ion cells during initial charging. J Power Sources 68:311-315
32. Sloop SE, Kerr JB, Kinoshita K (2003) The role of Li-ion battery electrolyte reactivity in performance decline and self-discharge. $\mathrm{J}$ Power Sources 119-121:330-337

33. Sasaki T, Abe T, Iriyama Y, Inaba M, Ogumi Z (2005) Formation mechanism of alkyl dicarbonates in Li-ion cells. J Power Sources 150:208-215

34. Shin J-S, Han C-H, Jung U-H, Lee S-I, Kim H-J, Kim K (2002) Effect of $\mathrm{Li}_{2} \mathrm{CO}_{3}$ additive on gas generation in lithium-ion batteries. J Power Sources 109:47-52

35. Kong W, Li H, Huang X, Chen L (2005) Gas evolution behaviors for several cathode materials in lithium-ion batteries. J Power Sources 142:285-291 